\title{
Prevention of sexual transmission of Zika virus
}

\author{
Anna Kuna ${ }^{1,2}$, Michał Gajewski ${ }^{3}$ \\ ${ }^{1}$ Department of Tropical and Parasitic Diseases, University Centre for Maritime and Tropical Medicine in Gdynia, Poland \\ ${ }^{2}$ Department of Tropical Parasitology, Institute of Maritime and Tropical Medicine in Gdynia, Medical University of Gdansk, Poland \\ ${ }^{3}$ Department of Infectious Diseases, Medical University of Gdansk, Poland
}

In relation to the interesting review by Korzeniewski et al. [1] concerning the Zika virus, we would like to highlight some new facts concerning the sexual transmission of the virus that have arisen recently. Although the first case of the suspected Zika virus human-to-human sexual transmission was reported by Foy et al. [2] as early as in 2011, making Zika the first and so far the only known sexually-transmitted human arboviral disease, only recently has this mode of transmission been proved beyond doubt [3].

Despite the initial reports suggesting that the virus might be present in the semen for up to 62 days [4], the recent data is even more alarming and prove that the virus shedding in semen may persist for 188 days or even longer [5]. These disturbing reports emphasize the need for further studies to find out how long can Zika virus be transmitted through sexual contact. It is, however, worth mentioning that the detection of the viral RNA alone in the semen does not prove yet that the virus is viable and capable of causing infection. In the light of evidence linking Zika virus infection to microcephaly in newborns, the United States Centres for Disease Control (CDC) and Prevention currently recommend certain steps to be taken in order to reduce or eliminate the risk of Zika sexual transmission. The CDC highlight the need for safe sex for 8 weeks to 6 months following the exposure only or the onset of symptoms [6].

Currently, the World Health Organisation (WHO) in its interim guidelines published on September 06, 2016 recommends that in regions with active Zika virus transmission health programmes should ensure that:

1) All people (male and female) with Zika virus infection and their sexual partners (particularly pregnant women) receive information about the risks of sexual transmission of Zika virus;

2) Men and women also get counselling on safer sexual practices, and be offered condoms. The consistent use of condoms is essential to prevent sexually transmitted infections, including human immunodeficiency virus (HIV), and unwanted pregnancy;

3) Sexually active men and women be correctly counselled and offered a full range of contraceptive methods to be able to make an informed choice about whether and when to become pregnant, in order to prevent possible adverse pregnancy and foetal outcomes;

4) Women who have had unprotected sex and do not wish to become pregnant due to concerns about Zika virus infection have ready access to emergency contraceptive services and counselling;

5) Pregnant women should practice safer sex or abstain from sexual activity for at least the whole duration of the pregnancy. Their partners should also be informed about this recommendation.

In the regions with no active Zika virus transmission, the WHO recommends the health programs they should ensure that:

1) Men and women returning from areas where transmission of Zika virus is known to occur should adopt safer sex practices or consider abstinence for at least 6 months upon return to prevent Zika virus infection through sexual transmission;

2) Couples or women planning a pregnancy, who are returning from areas where transmission of Zika virus is known to occur, are advised to wait at least 6 months before trying to conceive to ensure that possible Zika virus infection has cleared;

3) Sexual partners of pregnant women, returning from areas where transmission of Zika virus is known to occur, should be advised to practice safer sex or abstain from sexual activity for at least the whole duration of the pregnancy [7].

The people traveling to areas with ongoing Zika virus transmission should also remember about standard methods of protection against insect bites (long-sleeved clothing,

Anna Kuna, MD, Department of Tropical and Parasitic Diseases, Institute of Maritime and Tropical Medicine in Gdynia, Medical University of Gdansk,

9b Powstania Styczniowego St., 81-519 Gdynia, Poland, e-mail: anna.kuna@gumed.edu.pl 
window screens and bed mosquito nets, insect repellents and insecticides). Due to the dynamic territorial expansion of Zika virus, the infection should also be considered in people who travelled to the countries without confirmed Zika virus transmission if the vector is present there [8]. In the diagnostic process, cross-reactivity with other arboviruses should be taken into account while using serological assays.

\section{REFERENCES}

1. Korzeniewski K, Juszczak D, Zwolińska E: Zika - another threat on the epidemiological map of the world. Int Marit Health 2016; 67: 31-37. doi: 10.5603/IMH.2016.0007.

2. Foy BD, Kobylinski KC, Foy JLC et al. Probable non-vector-borne transmission of Zika virus, Colorado, USA. Emerg Infect Dis 2011; 17: 880-882.
3. D'Ortenzio E, Matheron S, Yazdanpanah Y et al. Evidence of sexual transmission of Zika virus. N Engl J Med 2016; 374: 2195-2198. doi: 10.1056/NEJMc1604449

4. Atkinson B, Hearn $P$, Afrough $B$ et al. Detection of Zika virus in semen [letter]. Emerg Infect Dis 2016 May. doi: 10.3201/eid2205.160107.

5. Nicastri E, Castilletti C, Liuzzi G, lannetta M, Capobianchi MR, Ippolito G: Persistent detection of Zika virus RNA in semen for six months after symptom onset in a traveller returning from Haiti to Italy, February 2016. Euro Surveill 2016; 21: 32. doi: 10.2807/1560-7917. ES.2016.21.32.30314.

6. http://www.cdc.gov/zika/prevention/protect-yourself-during-sex.html.

7. World Health Organization: Prevention of sexual transmission of Zika virus. Interim guidelines update. WHO/ZIKV/MOC/16.1 Rev.3, Sep 06, 2016.

8. Mansuy JM, Pasquier C, Daudin M et al. Zika virus in semen of a patient returning from a non-epidemic area. Lancet Infect Dis 2016; 16: 894-895. doi: 10.1016/S1473-3099(16)30153-0. 